\title{
Design and Analysis of a Novel Drying Chamber in Indirect Forced Convection Solar Drying
}

\author{
Sabareesh Vijayakumar, Milan K. John, C. Muraleedharan, B. Rohinikumar
}

\begin{abstract}
Long drying time and less control on drying parameters in natural convection drying give way to forced convection indirect solar drying. In forced convection drying, an external blower supplies ambient air into the solar collector. The incoming air gets heated inside the collector and this air then flows into the drying chamber where the product to be dried is kept. The hot air absorbs the moisture from the raw crops and exits through the chimney. Along with the temperature and humidity of incoming air, its distribution inside the drying chamber is also important in the process of drying. The drying rate and quality can be improved if these parameters are under control in forced convection solar drying. In this paper, design and analysis of a novel drying chamber are presented to improve the performance and energy efficiency of solar drying with effective distribution of air inside the chamber. The variation of velocity with respect to different positions inside the drying chamber is also studied numerically.
\end{abstract}

Keywords: energy efficiency, solar drying chamber, temperature, velocity.

\section{INTRODUCTION}

In forced convection solar drying an external blower is used to pass local air into the solar flat plate collector which is inclined at the latitude angle to maximize the incident solar radiation. The top portion of the solar collector is covered with glass and the inner surface of the collector is painted black and insulated on sides to avoid heat losses. The hot air arriving from the collector then passes into the drying chamber that houses the product to be dried. In conventional solar drying chambers, inlet air enters from the bottom or side of the drying chamber, enters through each tray successively from bottom to top and exits through top duct. This causes a reduction in the temperature and increased moisture in the air available at each tray which adversely affects the quality of drying. It is essential to enhance the performance of present driers in the area of uniform drying because uneven drying increases the chance of product spoilage by fungus and bacterial attack which lowers its quality [1]. Moreover, it is observed that most of the solar driers used for experimentation are lacking a basic design procedure.

Revised Manuscript Received on July 05, 2020.

* Correspondence Author

Sabareesh Vijayakumar*, Student, Department of Mechanical Engineering, National Institute of Technology, Calicut, Kerala, India. E-mail: sabareeshvijayakumar95@gmail.com

Milan K. John, Student, Department of Mechanical Engineering, National Institute of Technology, Calicut, Kerala, India.

C. Muraleedharan, Student, Department of Mechanical Engineering, National Institute of Technology, Calicut, Kerala, India.

B. Rohinikumar, Student, Department of Mechanical Engineering, National Institute of Technology, Calicut, Kerala, India.
One of the prominent tools that is being used in various fields of food drying applications to predict and analyze the changes is computational fluid dynamics (CFD). It has successfully turned out to determine the velocity of flow at any location inside the solar drying chamber [1]. As mentioned before, the air flow distribution inside drying compartment has to be uniform because it is critical in improving both the efficiency as well as the consistency in flavor, texture and color of the products dried [2]. In this study, the drying chamber is so designed in such a manner that it ensures good capacity, with improved distribution of air to obtain uniform drying conditions. In addition to this, the velocity inside the chamber is determined with the help of fluid flow analysis in Ansys Fluent software. The geometrical complexity has to be minimized for the CFD models that are subjected to analysis because it helps to reduce time of both execution and updating. The basis of the two-dimensional modelling is that it presumes one of the physical dimensions of a system is much lesser than its other two dimensions, so that the entire flow process is happening normal to the smaller dimension [3]. Therefore in this work, a two dimensional CFD analysis is performed with the input data available from the theoretical results in order to obtain maximum distribution (maximum velocity/uniform distribution) of air inside the spatial arrangement for drying. From the results of CFD analysis, the velocity contours and the velocity variation inside the chamber are obtained.

\section{DESIGN OF DRYING CHAMBER}

\section{A. Design Consideration}

Calicut is located in the state of Kerala, India $\left(11.2588^{\circ} \mathrm{N}\right.$, $75.7804^{\circ} \mathrm{E}$ ) having monthly average solar global radiation of $20.628 \mathrm{MJ} / \mathrm{m}^{2} /$ day. The drier is designed for a maximum capacity of $10 \mathrm{~kg}$. Due to the medicinal value and the requirement of dried product in the field of medicine, ginger is taken as the raw material to be dried. It has generally an average initial moisture content of $80 \%$ and can be brought to average final moisture content of 5\% through solar drying $[4,5]$. The solar collector used for drying has an area of 0.9 $\mathrm{m}^{2}$ with an average collector efficiency of $25 \%$.

\section{B. Design Procedure}

Total mass of moisture which has to be removed from the raw product $\left(W_{w}\right)[6]$

$W_{w}=\frac{\left(M_{i}-M_{f}\right) x W_{p}}{100-M_{f}}$

$W_{p}$ : total mass of the product that is to be dried $(\mathrm{kg})$

$M_{i}$ : initial moisture content of the sample on wet basis (\%)

$M_{f}$ : final moisture content of the sample on wet basis (\%)

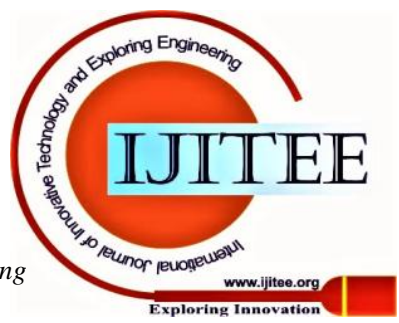




\section{Design and Analysis of a Novel Drying Chamber in Indirect Forced Convection Solar Drying}

Quantity of heat required to evaporate water content from the product,

$Q=W_{w} h_{f g}$

$h_{f g}$ : Latent heat of vaporization of moisture present inside the product $(\mathrm{kJ} / \mathrm{kg})$

Enthalpy of air entering the collector $(\mathrm{kJ} / \mathrm{kg})$,

$h_{i}=1.007 t_{d l}+\omega_{1}\left[2501+1.84 t_{d l}\right]$

Enthalpy of air leaving the collector $(\mathrm{kJ} / \mathrm{kg})$

$h_{f}=1.007 t_{d 2}+\omega_{2}\left[2501+1.84 t_{d 2}\right]$

$t_{d l}$ : Inlet air dry bulb temperature $\left({ }^{\circ} \mathrm{C}\right)$

$t_{d 2}$ : Outlet air dry bulb temperature $\left({ }^{\circ} \mathrm{C}\right)$

$\omega_{l}$ : Inlet air moisture content $(\mathrm{kg} / \mathrm{kg})$

$\omega_{2}$ : Outlet air moisture content $(\mathrm{kg} / \mathrm{kg})$

$\omega_{2}=\omega_{1}$ (assuming sensible heating inside the collector)

Total heat carried by air heated inside the collector,

$E=\dot{m}_{a}\left(h_{f}-h_{i}\right)$

$\mathrm{n}_{a}$ : mass flow rate of air

Efficiency of collector used $\eta=\frac{E}{I_{h} A_{c}}=\frac{\dot{\mathrm{m}}_{a}\left(h_{f}-h_{i}\right)}{I_{h} A_{c}}$

$A_{c}$ : Area of the collector $\left(\mathrm{m}^{2}\right)$

$I_{h}$ :Monthly average global solar radiation intensity $\left(\mathrm{W} / \mathrm{m}^{2}\right)$

or $\quad \dot{\mathrm{m}}_{a}=\frac{I_{h} \eta A_{c}}{\left(h_{f}-h_{i}\right)}$

Volumetric flow rate $=\frac{\text { mass flow rate of air }}{\text { density of air }}\left(\mathrm{m}^{3} / \mathrm{s}\right)$

The velocity of air is measured using an anemometer (which is used for experimental purpose) at the exit conduit of solar collector.

Base area of drying chamber

$=\frac{\text { Volume flow rate }}{\text { velocity of air at exit of collector }}\left(\mathrm{m}^{2}\right)$

Table-I: Output data from design of drying chamber

\begin{tabular}{|l|l|l|}
\hline $\begin{array}{l}\text { S. } \\
\text { No }\end{array}$ & $\begin{array}{l}\text { Specification of drying } \\
\text { chamber }\end{array}$ & Value \\
\hline 1. & Base area (approx.) & $0.5625 \mathrm{~m}^{2}$ \\
\hline 2. & Length & $0.75 \mathrm{~m}$ \\
\hline 3. & Breadth & $0.75 \mathrm{~m}$ \\
\hline 4. & Distance between trays (assumed ) & $0.15 \mathrm{~m}$ \\
\hline 5. & $\begin{array}{l}\text { Distance from tray to the edges } \\
\text { (assumed) }\end{array}$ & $0.2 \mathrm{~m}$ \\
\hline 6. & Height (From 4 \& 5) & $0.7 \mathrm{~m}$ \\
\hline
\end{tabular}

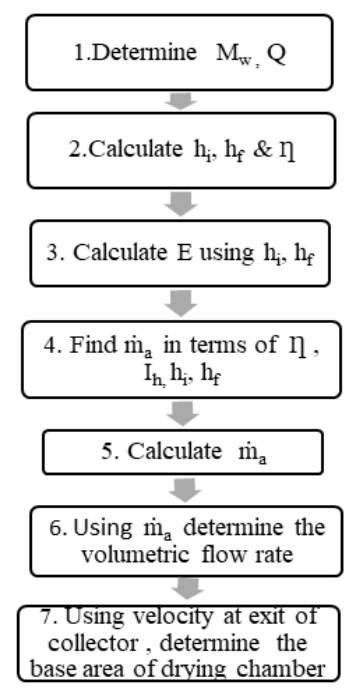

Fig. 1. Flowchart showing design procedure

\section{CFD ANALYSIS OF DRYING CHAMBER}

The computational fluid dynamic analysis is carried out using Ansys Fluent (2019) software. The objective of the analysis is to ensure maximum distribution of air inside the drying chamber. The details of the boundary conditions are as shown in Table II.

In the conventional design of drying chamber, the flowing air heated inside the solar collector is guided to enter into the drying chamber from its bottom side and this hot air then passes through the bottom most tray and subsequently the middle tray and then the top tray. However this brings about considerable reduction in temperature and increase in moisture content at each tray. Therefore a duct is designed to pass the hot air from the solar collector (entering at A as shown in Fig. 2) into the drying chamber. The duct splits into three branches leading to the position of three trays (at B1, B2, B3) so that each branch can convey the hot air at equal velocity with minimal edge loss into the trays. If the length $\mathrm{L}$ becomes too small, it is observed that there is more edge loss occurring at the smaller radius of curvature in the duct. Also, length $\mathrm{L}$ cannot be increased indefinitely. So there must be an optimum length $\mathrm{L}$ for minimising this loss. From the dimensions of drying chamber calculated in the design procedure, the height $\mathrm{H}$ of the duct is obtained as $350 \mathrm{~mm}$ and the distance between the trays is allowed to be $150 \mathrm{~mm}$ and an optimised length $\mathrm{L}$ is obtained by trial and error approach in CFD analysis such that there is equal mass flow rate (least edge loss) in each branch. The number of mesh elements is optimized to be 2245 and number of nodes to be 2360 approximately.

Table-II: Boundary conditions for CFD Analysis

\begin{tabular}{|c|c|c|}
\hline S.No & $\begin{array}{c}\text { Boundary } \\
\text { condition }\end{array}$ & Description \\
\hline 1. & Analysis type & 2-D Transient flow \\
\hline 2. & Turbulence model & $\begin{array}{c}\text { K-epsilon with standard wall } \\
\text { functions }\end{array}$ \\
\hline 3. & Fluid domain & Air \\
\hline 4. & Inlet type & Velocity inlet $(7.5 \mathrm{~m} / \mathrm{s})$ \\
\hline 5. & Outlet type & $\begin{array}{c}\text { Outlet vent } \\
\text { (Gauge Pressure: } 0 \mathrm{~Pa})\end{array}$ \\
\hline 6. & Wall & Stationary type \\
\hline 7. & Time step & 10000 \\
\hline 8. & $\begin{array}{c}\text { Number of time } \\
\text { steps }\end{array}$ \\
\hline
\end{tabular}




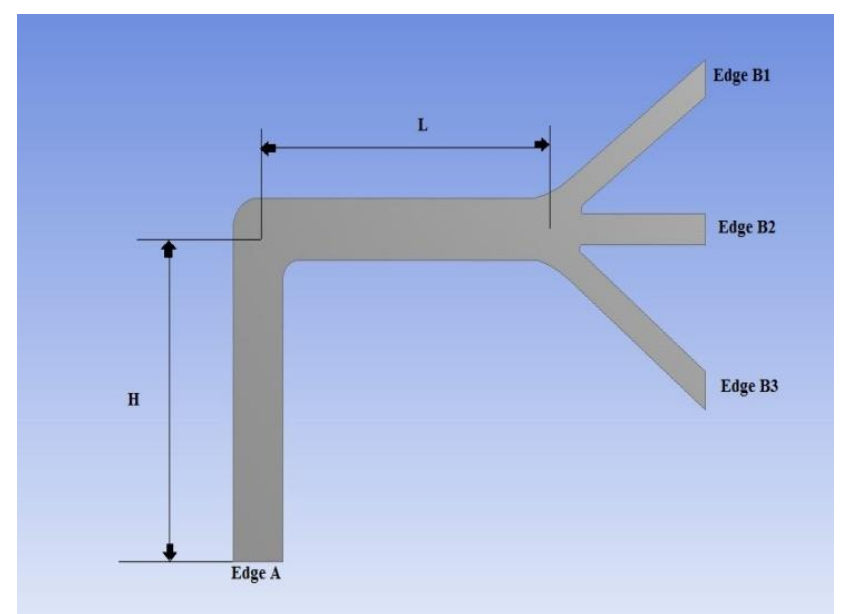

Fig. 2. Domain of fluid flow

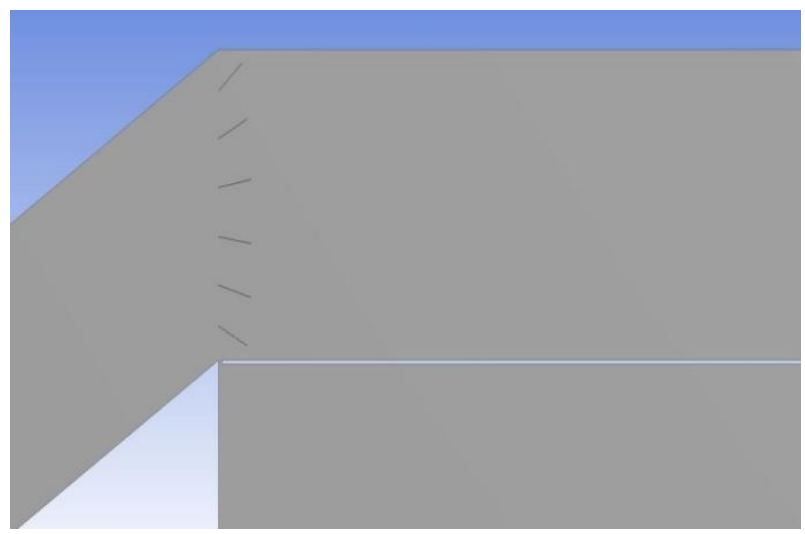

Fig. 3. Grill at exit of duct (right plane sectional view)

It is known from the design that the entering velocity of air is high, hence there is high chance that the dispersion of air may not take place properly inside the chamber. So the effect of installing grills at the diverging passage of the edges B1, B2 and B3 is studied. This gives a comparative analysis of air distribution in the chamber with and without grills. The grill type used in the analysis is spread with diverging vane $\left(15^{\circ}\right.$ angle) and the blade spacing is 0.5 inch as shown in Fig. 3 and 4.

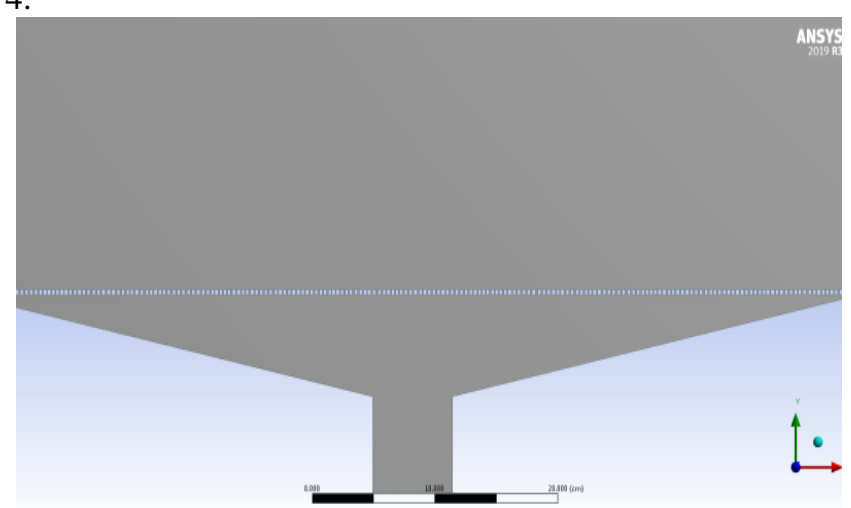

Fig. 4. Grill at exit of duct (top view)

The air distribution pattern inside the drying chamber is studied with trays attached (keeping boundary condition as wall for the trays). The distribution is studied with grills and without grills (right plane analysis). The number of outlet air vents in the drying chamber is also considered in the analysis (top plane analysis) to find its effect on the air distribution pattern inside the drying chamber. A single outlet, two outlets and three outlets are considered for analysis with grill attached at the air entry.

\section{RESULTS AND DISCUSSION}

The CFD analysis is performed with the input data to analyse the performance of the drying chamber and to study the nature of velocity spreading inside it. The duct air inlet velocity (at A) is measured to be $7.5 \mathrm{~m} / \mathrm{s}$ as mentioned in design procedure. The velocity contours are obtained as given in Fig. 5. In each of the branches B1 and B2, an average velocity of $5.5-6.2 \mathrm{~m} / \mathrm{s}$ is obtained while in branch B3, in the range of 4.15 to $4.84 \mathrm{~m} / \mathrm{s}$. This is mainly due to edge loss occurring at the smaller radius of curvature in the duct which is transporting hot air into the chamber. The region of edge loss can be identified by the red contours in the velocity contour of duct as shown in Fig.5. The edge loss brings about reduction in velocity in branch containing B3 compared to that of B1.

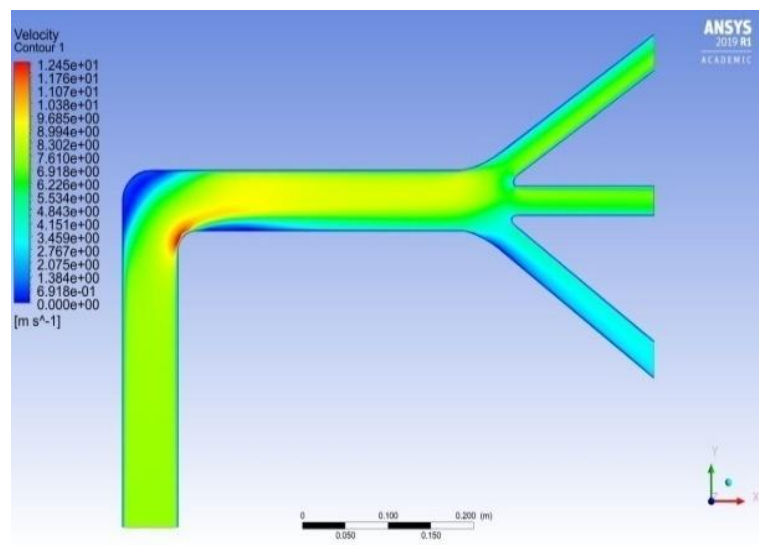

Fig. 5. Velocity contour of duct

The velocity contour is obtained for the chamber in right plane analysis without grill is as shown in Fig. 6 given below with the trays (thickness $10 \mathrm{~mm}$ ) that are extending horizontally along the length of the chamber. The trays are given boundary condition as wall (stationary type). The stream of warm air exits through the outlet vents placed at the end of each trays.

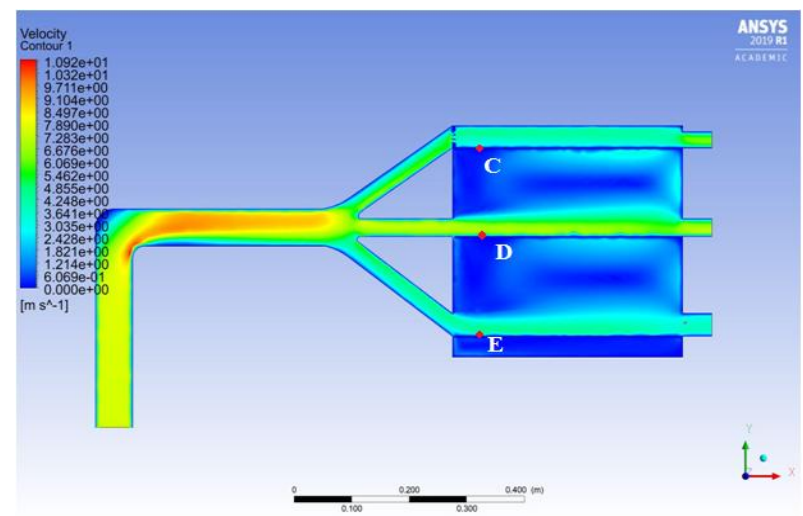

Fig. 6. Velocity contour of duct with chamber and trays (without grill)

Using the velocity contour obtained, the velocity is plotted against distance $(\mathrm{x}$ ) lengthwise of the chamber, at a constant distance $\mathrm{y}$ above the tray ( $\mathrm{y}$ is measured in vertical direction from the points C, D, E as shown in Fig. 6 for each of the tray regions Tray 1, Tray 2 and Tray 3, respectively). The plots are obtained for y values

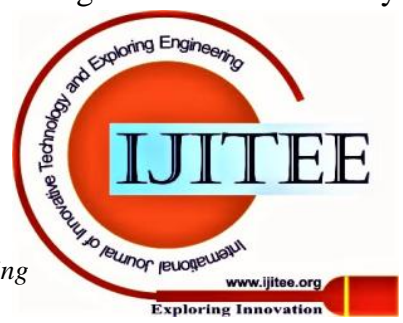




\section{Design and Analysis of a Novel Drying Chamber in Indirect Forced Convection Solar Drying}

$0.012 \mathrm{~m}, 0.024 \mathrm{~m}$ and $0.036 \mathrm{~m}$ for each tray regions (Tray 1: Upper tray, Tray 2: middle tray and Tray 3: bottom tray) (Refer Figs. 7, 8, 9). It can be observed that middle tray (Tray-2) is having a slightly higher velocity than the other two trays due to the bend loss in the flow and also there is an uneven variation in velocity for the three trays.

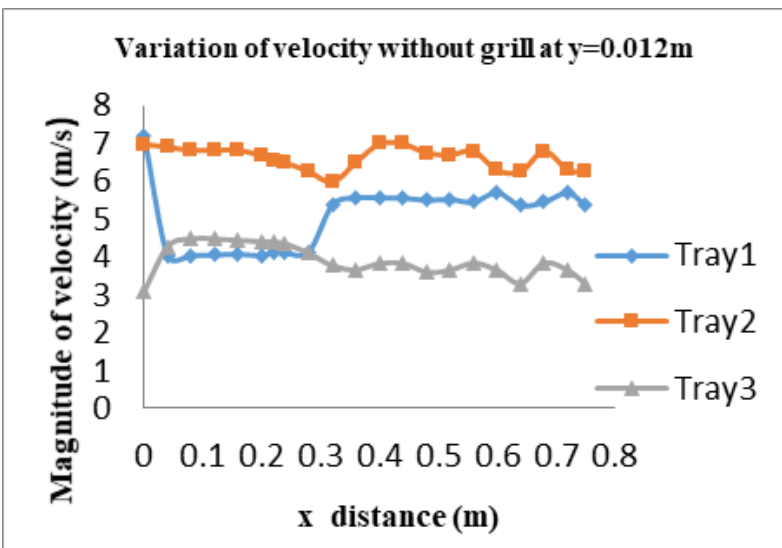

Fig. 7. Variation of velocity without grill at $y=0.012 m$

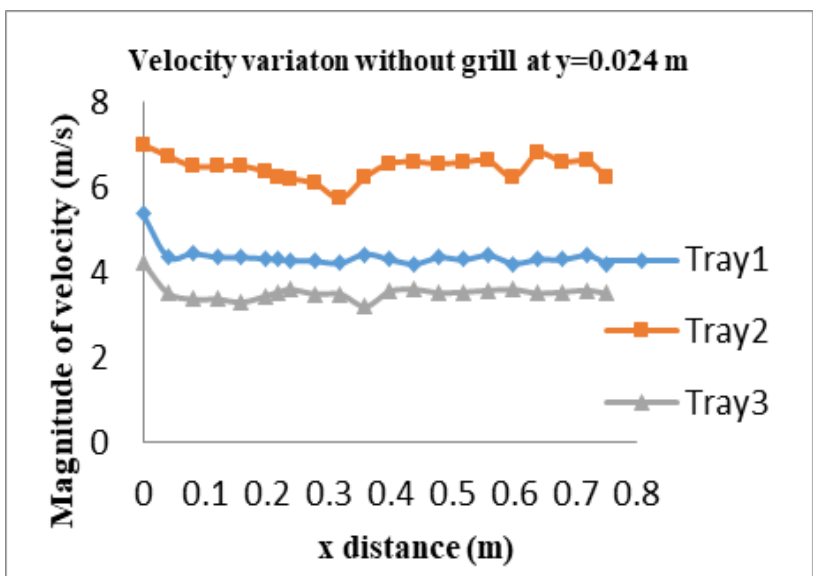

Fig. 8. Variation of velocity without grill at $y=0.024 m$

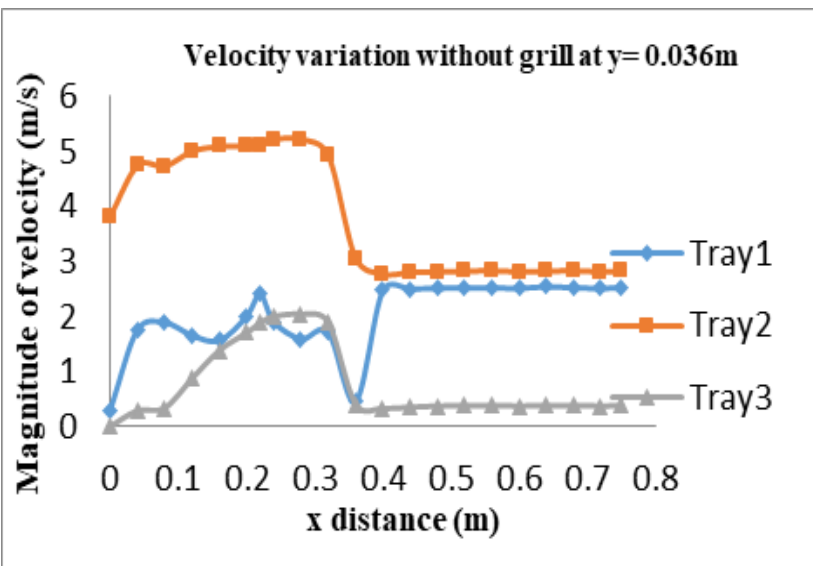

Fig. 9. Variation of velocity without grill at $\mathbf{y}=\mathbf{0 . 0 3 6 m}$

At $\mathrm{y}=0.012 \mathrm{~m}$, for the region in Tray 1 , an average velocity of $4.69 \mathrm{~m} / \mathrm{s}$ is obtained while an average velocity of $6.64 \mathrm{~m} / \mathrm{s}$ is obtained for region in Tray 2 and $4.106 \mathrm{~m} / \mathrm{s}$ for region in Tray 3.

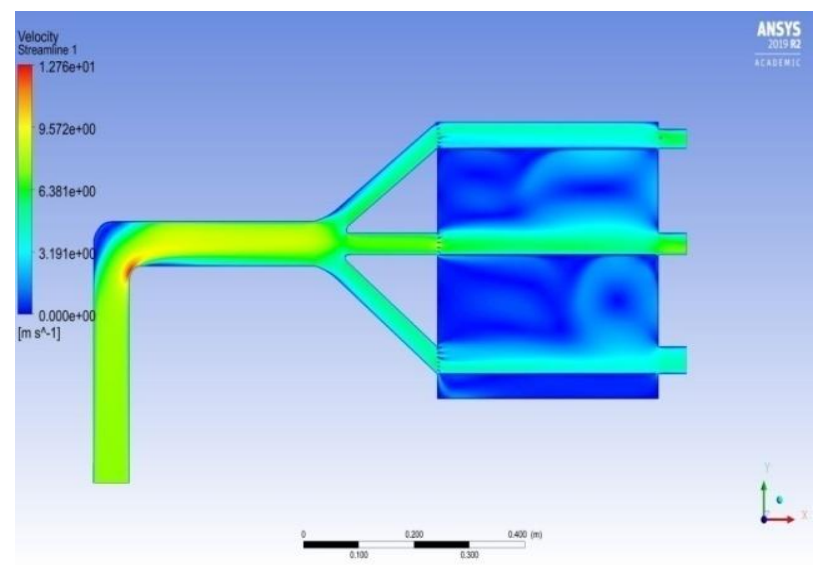

Fig. 10. Velocity contour of duct with chamber and trays (with grill)

Similarly at $\mathrm{y}=0.024 \mathrm{~m}$, an average velocity of $4.41 \mathrm{~m} / \mathrm{s}$ is observed in Tray 1 while for Trays 2 and 3, $6.386 \mathrm{~m} / \mathrm{s} 3.51$ $\mathrm{m} / \mathrm{s}$, respectively. At $\mathrm{y}=0.036 \mathrm{~m}$, the average velocities found are respectvely $1.04,4.56$ and $1.09 \mathrm{~m} / \mathrm{s}$ in Tray 1 , Tray 2 and Tray 3 . The velocity contour (Fig. 10) is also obtained with grills attached in the duct so that it enhances the distribution of air within. The velocity plot gives a general trend in the variation of velocity. The plots are obtained for $y$ values $0.012 \mathrm{~m}, 0.024 \mathrm{~m}, 0.036 \mathrm{~m}$ for each tray region (Figs. 11, 12, 13). The use of grills at the chamber inlet cause the dispersion of the air stream more effectively as it can be observed from Fig.5 \&6 . It may be inferred from the graphs that the difference in velocity magnitude amongst the trays is minimum at $\mathrm{y}=0.024 \mathrm{~m}$.

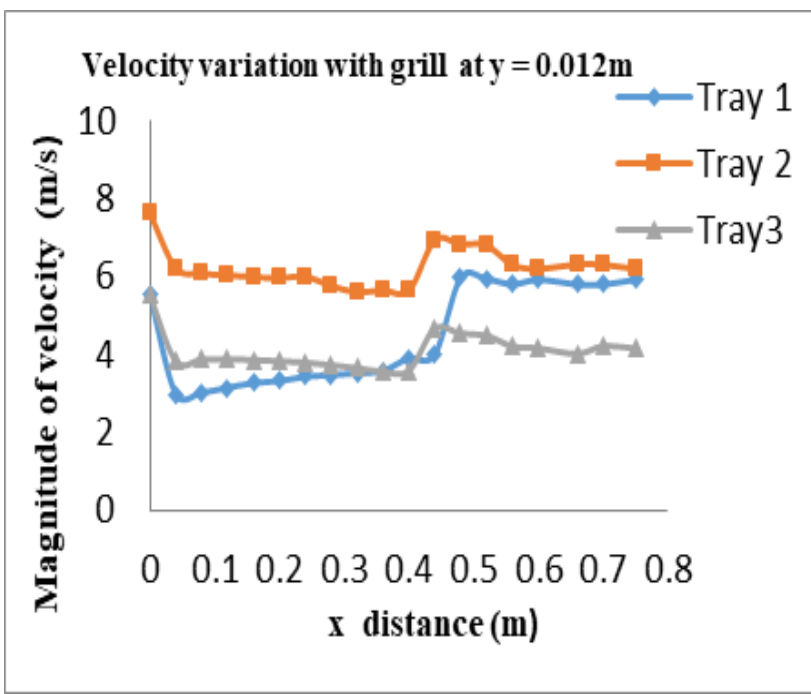

Fig. 11. Variation of velocity with grill at $y=0.012 \mathrm{~m}$

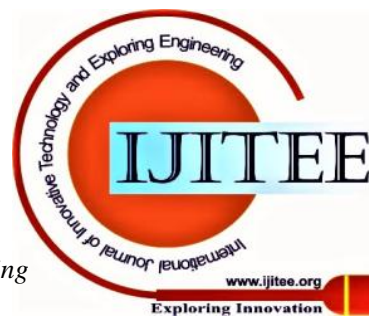




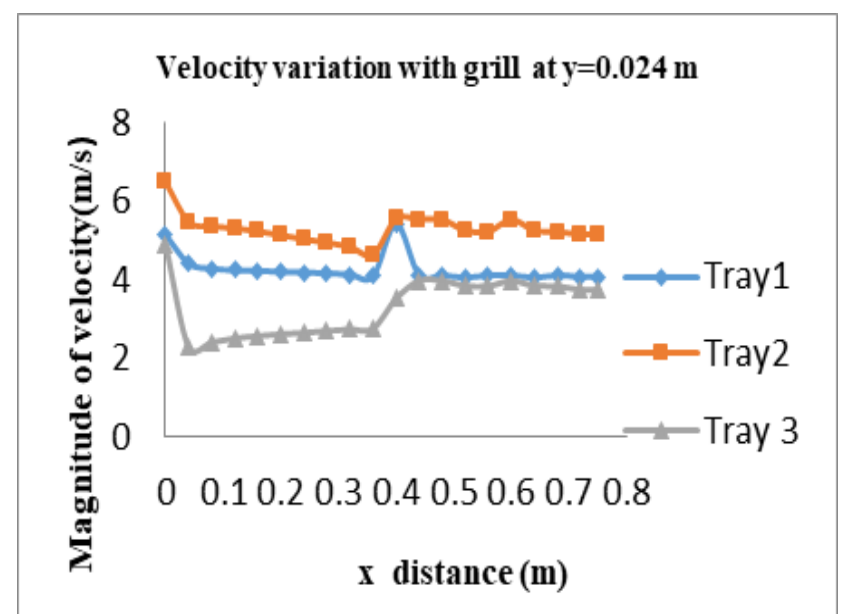

Fig. 12. Variation of velocity with grill at $y=0.024 m$

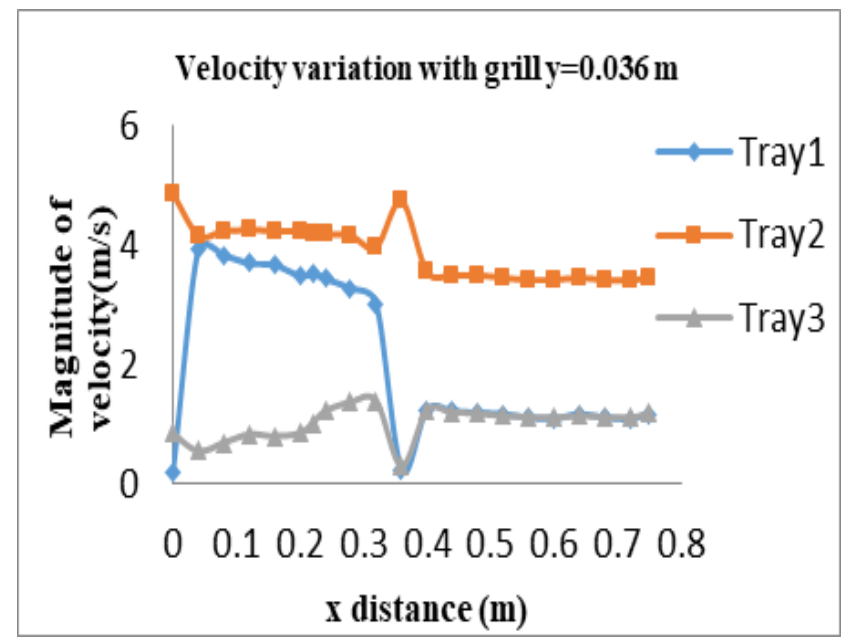

Fig. 13. Variation of velocity with grill at $\mathbf{y}=\mathbf{0 . 0 3 6 m}$

At $y=0.012 \mathrm{~m}$, the average velocity in Tray 1 is found as 3.51 $\mathrm{m} / \mathrm{s}$ and in Tray 2 and 3 it is $6.22 \mathrm{~m} / \mathrm{s}$ and $4.05 \mathrm{~m} / \mathrm{s}$. The average velicties are found to be $4.39,5.3$ and $2.96 \mathrm{~m} / \mathrm{s}$ at $\mathrm{y}=0.024 \mathrm{~m}$ and $2.80 \mathrm{~m} / \mathrm{s}, 4.24 \mathrm{~m} / \mathrm{s}$ and $0.90 \mathrm{~m} / \mathrm{s}$ at $\mathrm{y}=0.036 \mathrm{~m}$, respectively for Trays 1, 2 and 3. The significant reduction in velocity in Tray 3 is due to edge losses.

The velocity contour is obtained for drying chamber (with grills attached) and with single, double and triple outlets for exit air from each tray to study its effect on the distribution of air. The velocity contours (Figs.14,15, 16) show that better air distribution pattern is obtained with three outlets and that with single outlet is showing minimum effective distribution. An average velocity of $2.2 \mathrm{~m} / \mathrm{s}$ is obtained inside the single outlet type and an average of $3.2 \mathrm{~m} / \mathrm{s}$, in two outlet type. Moreover, it can be observed that more votex formation is taking place in this type. which adversely affects the normal exiting of the air stream. In three outlet type it can be observed that stream of air entering the chamber experiences better spatial distribution of air with an average velocity of $2.9 \mathrm{~m} / \mathrm{s}$.

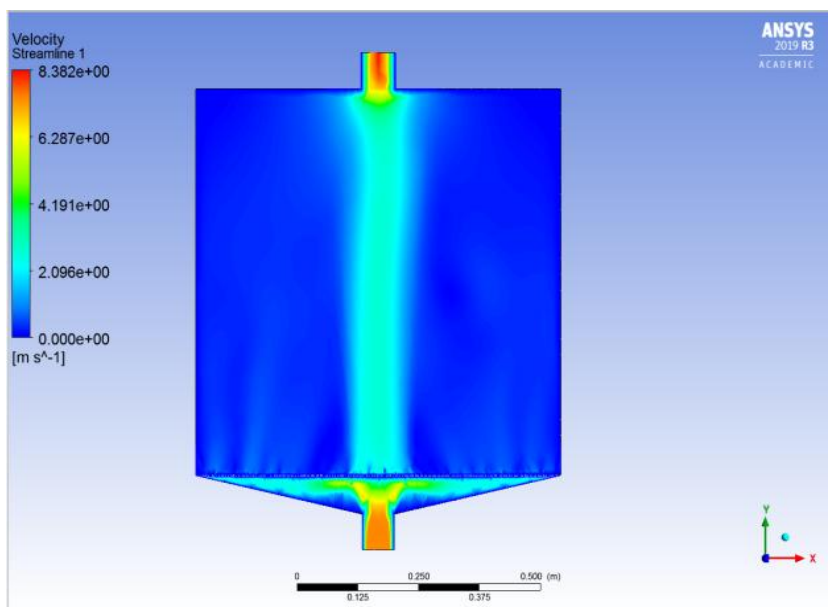

Fig.14. Velocity contour with one outlet

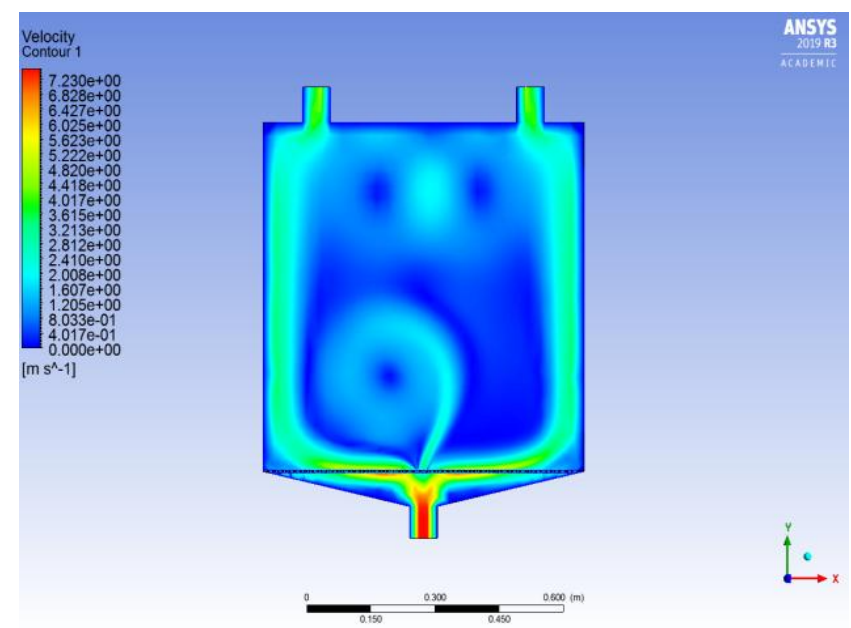

Fig. 15. Velocity contour with two outlets

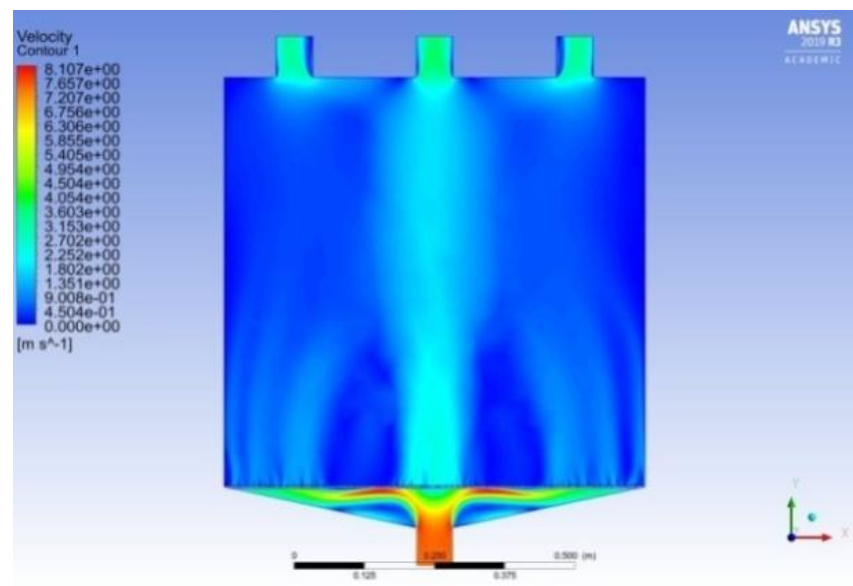

Fig. 16. Velocity contour with three outlets

\section{CONCLUSION}

A good design of drying chamber ensures more air distribution and better drying of raw products. The velocity of air is also an important factor in determining the drying time of the products. A uniform mass flow rate of air into each tray is obtained with the duct arrangement. From the velocity plot of the duct and chamber arrangement with trays it is observed that at $\mathrm{y}=0.036 \mathrm{~m}$ (which is located more inside the chamber) there is an increase in velocity by $16.9 \%, 7.23 \%$ and $16.7 \%$ in each of the tray regions of Tray 1, Tray 2 and Tray 3,

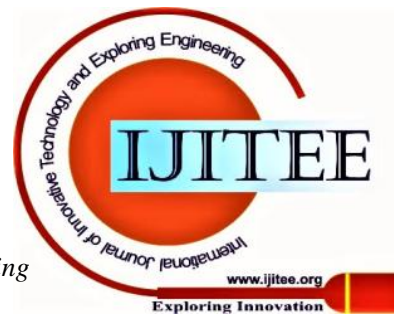




\section{Design and Analysis of a Novel Drying Chamber in Indirect Forced Convection Solar Drying}

respectively by the use of grills compared to without it. Moreover, the distribution of air inside the chamber is enhanced by the use of supply air grill. The non-uniform variation in velocity at several locations inside the drying chamber can be accounted for the backflow conditions existing inside the chamber. The velocity contour is obtained for chamber with three different number of outlets and amongst them better air distribution is obtained with three outlets. The number of outlet vents is also an important factor in determining the air distribution in drying chamber.

\section{REFERENCES}

1. Petros Demissie, Mesele Hayelom, Amanuel Kassaye, Asfafaw Hailesilassie, Meknonnen Gebrehiwot, Maarten Vaneirschot, "Design, development and CFD modeling of indirect solar food dryer", Energy Procedia vol.158, p 1128-1134, 2019.

2. H. Darabi, A. Zomorodian, M.H. Akbari, A.N. Lorestani, "Design of a cabinet dryer with two geometric configurations using CFD , Journal of Food Science and Technology", 52 p. 359-366, 2015.

3. T. Norton, B. Tiwari, D.-W. Sun, "Computational fluid dynamics in the design and analysis of thermal processes: a review of recent advances", Crit. Rev. Food Sci. Nutr. 53 251-75, 2013.

4. J. Prasad and V. K. Vijay, "Experimental studies on drying of Zingiber officinale, Curcuma longa 1. and Tinospora cordifolia in solar-biomass hybrid drier," Renew. Energy, vol. 30, no. 14, pp. 2097-2109, 2005..

5. J. Eze and K. Agbo, "Comparative studies of sun and solar drying of peeled and unpeeled ginger," Am. J. Sci. Ind. Res., vol. 2, no. 2, pp. 136-143, 2011

6. M. N. Musembi, K. S. Kiptoo, and N. Yuichi, "Design and Analysis of Solar Dryer for Mid-Latitude Region," Energy Procedia, vol. 100, no. September, pp. 98-110, 2016.

7. A. Lingayat, V. P. Chandramohan, and V. R. K. Raju, "Design, Development and Performance of Indirect Type Solar Dryer for Banana Drying," Energy Procedia, vol. 109, no. November 2016, pp. 409-416, 2017.

8. Sharma, A., Chen, C.R., Lan, N. V., "Solar-energy drying systems: A review, Renewable and Sustainable Energy Reviews",vol.13, pp. 1185-1210, 2009.

9. Youcef-Ali S., Messaoudi H., Desmons J.Y., Abene A., Le Ray M. "Determination of the Average Coefficient of Internal Moisture Transfer during the Drying of a Thin Bed of Potato Slices, Journal of Food Engineering", 48(2), p. 95-101, 2001

\section{AUTHORS PROFILE}

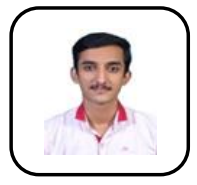

Sabareesh Vijayakumar is pursuing M. Tech in Energy Engineering and Management in the Department of Mechanical Engineering, National Institute of Technology Calicut. He is currently doing his M. Tech project work in the area of desiccant assisted solar drying of crops. His area of interest includes Renewable energy systems and Refrigeration systems

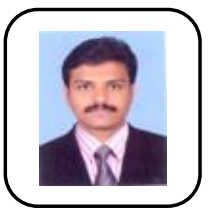

Milan K John is currently doing his $\mathrm{Ph}$. D. in Mechanical Engineering Department, National Institute of Technology Calicut. His research work is mainly focused in the area of novel and cost effective solar drying systems

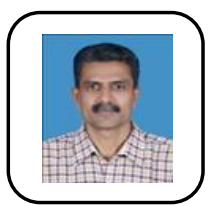

C. Muraleedharan is Professor in Department of Mechanical Engineering at National Institute of Technology Calicut, Kerala, India. His research interests include Fuels and combustion, Heat pipes and Energy conservation.

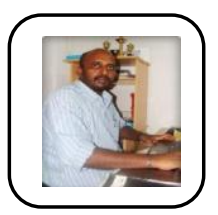

B Rohinikumar obtained his Ph.D Degree in Mechanical Engineering from National Institute of Technology, Calicut (2018). He completed his Master's degree in Thermal Power Equipment from R.E.C Trichy (2002). He is currently working as Assistant Professor in Department of Mechanical Engineering in National institute of Technology, Calicut. His research interest include Fluid flow and heat transfer, Modelling and simulation of Solar Energy Systems, Experimental investigations on Solar Energy systems and Refrigeration \& Air Conditioning systems. 